\title{
LOUVAIN NATURAL RADIOCARBON MEASUREMENTS VI
}

\author{
E. GILOT
}

Department of Nuclear Chemistry, University of Louvain, Louvain, Belgium

The following list comprises a selected number of measurements made during 1966-67 with $\mathrm{CH}_{4}$ at $3 \mathrm{~atm}$ pressure in a $0.6 \mathrm{~L}$ proportional gas-counter as previously described. The B.P. ages are based upon A.D. 1950 and are calculated with a half-life of $5570 \mathrm{yr}$. The quoted error consists of experimental standard deviation including the counting variations of the unknown sample, the modern standard, and the background.

Sample clescriptions have been prepared in collaboration with the submitter.

Sincere thanks are due Prof. P. Capron for his constant guidance. Thanks are also due F. Frix for his help in laboratory work, and to G. Michotte for maintenance of electronics. Financial support has been provided by the Institut Interuniversitaire des Sciences Nucléaires, Brussels.

\section{SAMPLE DESCRIPTIONS}

The following series from the Bas-Luxembourg are described in the monograph of palynology (Couteaux, 1967), establishing vegetational phases of Tardiglacial and Holocene periods, and studying geomorphological evolution of the country, particularly development of peat-bogs, travertine layers, and the "mardels." All samples were coll., subm., and pollen-analyzed by M. Coûteaux, Univ. of Louvain, Lab. of Palynology. The monograph also discusses other $\mathrm{C}^{14}$ dates previously published, namely Lv-56 (Louvain I), Lv-20-23 (Louvain II), Lv-30 (Louvain III), I.v-188 (Louvain V), Gr N-2868-2886 (Groningen V), Lv-72 (Mertens, $1960)$.

\section{Stockem IV series}

Samples from a bog at Stockem $\left(49^{\circ} 41^{\prime} 00^{\prime \prime} \mathrm{N}\right.$ Lat, $5^{\circ} 46^{\prime} 20^{\prime \prime} \mathrm{E}$ Long), Prov. of Luxemburg, Belgium, alt $370 \mathrm{~m}$. Cioll. 1964.

\section{Lv-215. Stockem IV /3}

$4060 \pm 140$ peat peat layer bottom. Pollen-dated to end of Atlantic period: higher values of Alnus, frequency of Fagus pollen lower than $1 \%$. Date agrees with palynology.

\section{Lv-214. Stockem IV/2}

$2030 \pm 100$ . Same vegetation as in Lv-215, but with a small increase of Fagus up to $2.5 \%$. Palynologically, Sub-Boreal age is expected; $\mathrm{C}^{14}$ date gives Sub-Atlantic age. Scarcity of Fagus is explained by acid substratum. 


\section{Lv-213. Stockem IV/ I}

$$
1480 \pm 110
$$

Peat from 50 to $60 \mathrm{~cm}$. Vegetation still similar. Carpinus pollen occurs sporadically. Date confirms Sub-Atlantic age of this phase.

\section{Breidfeld I series}

Samples from bog at Breidfeld $\left(50^{\circ} 07^{\prime} 22^{\prime \prime} \mathrm{N}\right.$ Lat, $8^{\circ} 05^{\prime} 04^{\prime \prime} \mathrm{E}$ Long), Luxemburg, alt. 440 m. Coll. 1964.

\section{Lv-212. Breidfeld $I / 3$}

$2560 \pm 120$

610 B.C.

Peat from 28 to $35 \mathrm{~cm}$. Pollen diagram shows, in curve of Fagus, maximum $(45 \%)$ followed by steep decrease to $10 \%$, while Betula rises. At the same time, corn pollen and signs of land occupation appear. Comparison with pollen diagrams of Wideumont and Namoussart (Bonenfant, 1965; Couteaux, 1962a; Guebel, 1962), indicate that this level is not the lst beech maximum (Fagus silvatica -F I), but corresponds to an artificial regression of beech curve because of human activity, probably during La Tene I time. $\mathrm{C}^{14}$ date confirms the conjecture.

\section{Lv-211. Breidfeld I/ 2}

$$
2680 \pm 110
$$$$
730 \text { B.C. }
$$

Peat from 35 to $39 \mathrm{~cm}$, immediately below preceding sample. Pollen diagram shows beginning of Fagus-increase. Both dates are consistent with each other and with palynological age.

\section{Lv-210. Breidfeld I/1}

$$
2350 \pm 100
$$

400 B.C.

Peat from 39 to $46 \mathrm{~cm}$, near base of peat. Pollen analysis: beginning of Sub-Atlantic period, immediately after time when Fagus definitively surpasses Quercetum mixtum, estimated age, 800 B.c. (Mullenders et al., 1967). According to palynology, $\mathrm{C}^{14}$ clate seems a little late.

\section{l.v-240. Berdorf-Aesbaach IV}

$9670 \pm 290$

7720 B.C.

Peat from Berdorf (49 $49^{\prime} 10^{\prime \prime} \mathrm{N}$ Lat, $8^{\circ} 27^{\prime} 12^{\prime \prime}$ E Long), Luxemburg, alt $190 \mathrm{~m}$. From an 8 -cm-thick peat lens in basis of travertine layer more than $5 \mathrm{~m}$ thick. Sample position: 4 to $8 \mathrm{~cm}$ in peat. Coll. 1965 . Pollen analysis shows pine forest, first scattered then more and more dense, attributed to beginning of Pre-Boreal age. Date agrees with results of pollen analysis. Calcareous sediment at Berdorf has been accumulating since Pre-Boreal period; it proves holocene warming. Comment: sample not leached with $\mathrm{NaOH}$ because of calcareous protection in situ.

\section{Lv-244. Muno-Amerois I}

$4790 \pm 110$

\section{B.C.}

Peat with small amounts of wood and rootlets from a bog, $146 \mathrm{~cm}$ thick, at Muno-Amerois (49 $44^{\prime} 38^{\prime \prime} \mathrm{N}$ Lat, $5^{\circ} 07^{\prime} 13^{\prime \prime} \mathrm{E}$ Long), Prov. of Luxemburg, Belgium, alt $415 \mathrm{~m}$. Sample from 116 to $130 \mathrm{~cm}$ depth. Coll. 1962. Pollen analysis shows end of an Atlantic phase rich in Ulmus. Sam- 
ple taken just above elm fall, during small increase of Corylus attributed to CX of Dricot (1960). Nearby, in forest of Anlier, Mullenders and Knop point out a true maximum $\mathrm{CX}$, the end of which is dated to 3170 в.C. (Lv-63, Louvain IV) and 2900 B.c. (Lv-51, Louvain III). Date indicates that in S Ardenne, elm fall date agrees with classical date of 3000 B.c. in NW Europe.

\section{Sainte Marie sur Semois-Mauvais Ruisseau I series}

Sample from bog of Mauvais Ruisseau $\left(49^{\circ} 40^{\prime} 06^{\prime \prime} \mathrm{N}\right.$ Lat, $5^{\circ} 33^{\prime} 14^{\prime \prime}$ E Long) at Sainte Marie sur Semois, Prov. of Luxemburg, Belgium, alt $345 \mathrm{~m}$. The $50-\mathrm{cm}$-thick peat layer is covered by $35 \mathrm{~cm}$ of clay. It is situated at $300 \mathrm{~m}$ from Roman road from Reims to Treves, archaeol. dated to 1st c. A.D. (Mertens, 1956), and at $700 \mathrm{~m}$ from important Roman villa. Coll. 1965.

\section{Lv-261. Sainte Marie sur Semois Mauvais Ruisseau $\mathbf{I} / \mathbf{a}$ \\ $2000 \pm 100$ \\ 50 B.C.}

Peat from 55 to $60 \mathrm{~cm}$ below ground surface. Pollen diagram shows forest clearance phase just when Fagus tends to dominate. At same level, peat contains a piece of presumably Roman brick. C ${ }^{14}$ date confirms bech maximum F I is masked in pollen curve by Gallo-Roman forest clearance.

\section{Lv-262. Sainte Marie sur Semois Mauvais Ruisseau I/b}

Peat with many rootlets from 64 to $71 \mathrm{~cm}$ below ground surface. Pollen curve indicates 5th hazel maximum (Corylus avellana-C IV). At Rouge Ponceau, the same is dated to 1030 B.c. \pm 170 (Lv-153, Louvain IV). In addition, Lv-211 (this list) shows that in 730 в.C. Fagus was increasing after decrease of Corylus. $\mathrm{C}^{14}$ date seems late presumably due to contamination by younger rootlets.

\section{Sainte Marie Chevigny series}

Wood samples (Quercus, id. by A. Munaut and J. Heim) from Sainte Marie Chévigny (49 $55^{\prime} 39^{\prime \prime} \mathrm{N}$ Lat, $5^{\circ} 27^{\prime} 21^{\prime \prime}$ E Long), Prov. of Luxemburg, Belgium, alt $470 \mathrm{~m}$. From a beam with 116 tree-rings embedded in ballast of ancient road hidden in 84-cm-thick peat layer. Coll. 1964. $\mathrm{C}^{1+}$ date confirms Roman origin of road, as found in $\mathrm{Lv}-30$ (Louvain III). Pollen profile taken near beam. As at Sainte Marie sur Semois-Mauvais Ruisseau (Lv-261, this list), Gallo-Roman forest clearance partly masks beech maximum $\mathrm{F}$ I.

\section{Lv-238. Sainte Marie Chévigny a \\ From 20 outer year-rings.}

\section{Lv-239. Sainte Marie Chévigny b}

From 20 inner year-rings.

$$
1990 \pm 120
$$$$
40 \text { в.c. }
$$

$1800 \pm 85$ 
Lv-220. Beaufort-Birkenbach I

Peat from bog, $100 \mathrm{~cm}$ thick, at Beaufort $\left(49^{\circ} 50^{\prime} 51^{\prime \prime} \mathrm{N}\right.$ Lat, $8^{\circ} 18^{\prime}$ $50^{\prime \prime}$ E Long), Luxemburg, alt $360 \mathrm{~m}$. Sample taken from 58 to $69 \mathrm{~cm}$ depth. Coll. 1964. Dates lst characteristic maximum F I in curve of beech.

\section{Rodenbourg-Bretzhoesch I series}

Samples from bog of Bretzboesch $\left(49^{\circ} 41^{\prime} 30^{\prime \prime} \mathrm{N}\right.$ Lat, $8^{\circ} 17^{\prime} 29^{\prime \prime} \mathrm{E}$ Long) at Rodenbourg, Luxemburg, alt $285 \mathrm{~m}$. Coll. 1965.

\section{Lv-243. Rodenbourg-Bretzboesch I/c}

$1620 \pm 100$

Peat from 166 to $175 \mathrm{~cm}$, at base of peat layer. End of beech maximum F I and beginning of Carpinus increase is reached at this level. At Beaufort, beech maximum F I is dated to 130 B.c. \pm 80 (Lv-220, this list). Both samples yield dates consistent with each other and with results of pollen analysis. Filling-up of this "mardel" by peat formation thus began in Sub-Atlantic period, as at Bonnert, shown palynologically by Coûteaux (1962 b).

\section{Lv-242. Rodenbourg-Bretzboesch I/l,}

$$
1440 \pm 90
$$

Peat from 128 to $136 \mathrm{~cm}$. Pollen diagram shows new increase of Fagus; Carpinus also rises. Radiocarbon age confirms beginning of 2nd beech maximum F II.

Lv-243. Rodenbourg-Bretzboesch I/a

$$
1330 \pm 90
$$

Peat from 108 to $116 \mathrm{~cm}$. Fagus alone dominates and Carpinus decreases. $\mathrm{C}^{14}$ date indicates continuation of 2 nd beech maximum $\mathrm{F}$ II. Same level is clated at Rulles to A.D. 740 and A.D. 970 (Lv-182 and I.v-183, this list) and A.D. 860 at Tontelange-Faascht (Lv-56, Louvain I).

\section{Rulles I series}

Wood samples (Fagus, id. by A Munaut and J. Heim) embedded in bog at Rulles (49 42' $31^{\prime \prime} \mathrm{N}$ Lat, $5^{\circ} 33^{\prime} 07^{\prime \prime} \mathrm{E}$ Long), Prov. of Luxemburg, Belgium, alt $375 \mathrm{~m}$. Coll. 1963.

\section{Lv-182. Rulles I/1}

$$
1210 \pm 75
$$

Large pieces of wood lying in peat layer from 39 to $47 \mathrm{~cm}$ below surface. At this level, pollen diagram shows increase of Fagus, which appears to be 2 nd beech maximum F II. C 14 age agrees with palynologic interpretation.

Lv-183. Rulles I/2

$$
980 \pm 120
$$

Sample from another large piece of wood from same level as in $\mathrm{Lv}_{\text {- }}$ 182. Both pieces were entangled. 


\section{Lv-196. Rulles I/3}

$1730 \pm 120$

Twigs of beech from $72 \mathrm{~cm}$ in peat layer. In pollen curves, Fagus dominates, but seems partly attenuated by partial forest clearance, probably Gallo-Roman during lst beech maximum F I. Date confirms interpretation. As at Rodenbourg (Lv-243, this list), peat formation in the "mardel" began during Atlantic period. Archaeologically, date proves that bottom of peat layer is not contemporary with two large pieces of beech thought by archaeologists (Loess, 1913) to be frame of prehistoric hut.

\section{Orval series}

Wood samples from Orval abbey $\left(49^{\circ} 38^{\prime} 31^{\prime \prime} \mathrm{N}\right.$ Lat, $5^{\circ} 20^{\prime} 18^{\prime \prime} \mathrm{E}$ Long) near Villers devant Orval, Prov. of Luxemburg, Belgium, alt 215 m. Coll. 1963.

\section{Lv-83. Orval 1963 b)}

A.D. 970

$980 \pm 110$

Wood (Fagus, id. by A. Munaut) from floor of hut which appears to be (Gregoire, 1964) out-house of 1st Benedictine settlement at Orval in A.D. 1070. Date is consistent with interpretation.

\section{Lv-84. Orval 1963 a}

$1040 \pm 80$

Pine stub (Pinus silvestris, id. by A. Munaut) in situ from peat layer between 2 travertine layers, $123 \mathrm{~cm}$ below ground surface. Pollen curve, in addition to discovery of stomata of Pinus, indicates that Pinus grew at Orval during Atlantic period. $\mathrm{C}^{14}$ date confirms palynologic interpretation.

Date lists:

\section{RFFERENCES}

$\begin{array}{ll}\text { Groningen V } & \text { Vogel and Waterbolk, 1964 } \\ \text { Louvain I } & \text { Dossin, Deumer, Capron, } 1962 \\ \text { Louvain II } & \text { Deumer, Gilot, Capron, 1964 } \\ \text { Louvain III } & \text { Gilot, Ancion, Capron, 1965 } \\ \text { Louvain IV } & \text { Gilot, Ancion, Capron, 1966 } \\ \text { Louvain V } & \text { Gilot, 1967 }\end{array}$

Bonenfant, P., 1965, Sept tombelles de Ia Tène I en Ardenne: Ardenne et Famenne, v. 8, p. $1-51$.

Coûteaux, M., 1962a. Analyse pollinique d'une tombelle de La Tène I à Namoussart: Ardenne belge: Archacologia Belgica, no. 61, p. 51-63.

1962b. Etude palynologique de la tourbière du Buchelbusch à Bonnert et de la toubic̀re du Heidelknapp à Tontelange: Soc. Royale Bot. Belgique Bull., v. 94, p. $261-278$.

1967, Evolution du paysage végétal du Bas-Luxembourg depuis le PléniWürm; thesis, Bot. Inst. Univ. Louvain, 413 p.

Deumer, J. M., Gilot, E., and Capron, P. C., 1964, Louvain Natural Radiocarbon Measurements II: Radiocarbon, v. 6, p. 160-166.

Dossin, J. M., Deumer, J. M., and Capron, P. C., 1962, Louvain Natural Radiocarbon Measurements I: Radiocarbon, v. 4, p. 95-99.

Dricot, E. M., 1960, Recherches palynologiques sur le Plateau des Hautes Fagnes: Soc. Royale Bot. Belgique Bull., v. 92, p. 157-196. 
Geubel, A., 1962, Chronique des fouilles dans les nécropoles à tombelles de La Tène en Ardenne belge: Archaeologia Belgica, no. 61, p. $51-63$.

Gilot E., 1967, Louvain Natural Radiocarbon Measurements V: Radiocarbon, v. 9, p. $295-300$.

Gilot, E., Ancion, N., and Capron, P.C., 1965, Louvain Natural Radiocarbon Measurements III: Radiocarbon, v. 7, p. $118-122$. p. $248-255$.

1966, Louvain Natural Radiocarbon Measurements IV: Radiocarbon, v. 8,

Gregoire, C., 1964, Contributions à l'histoire de l'abbaye d'Orval. Ancien cloître. Historique de son évolution: Le Pays Gaumais, v. 24-25, p. 259-276.

Loess, F., 1913, La mardelle de Rulles. Fouilles d'une mardelle de grande dimension i Rulles: Inst. Archaeol. du Luxembourg Annales, v. 48, p. 424-438.

Mertens, J., 1956, La chaussée romaine de Reims à Trèves: Le Pays Gaumais, v. 17, p. $91-115$.

1960, Le Kaarlsbierg à Clairefontaine et quelques autres fortifications anciennes du Luxembourg Méridional: Soc. Royale du Patrimoine Artistique Bull., v. 3 , p. $63-89$.

Mullenders, W. et al., 1967, The evolution of the vegetation in High Belgium and isotope dating, in: Cushing, E. J. and Wright, H. E., Jr., Eds., Quarternary Paleoecology, New Haven, p. 333-339.

Vogel, J. C. and Waterbolk, H. T., 1964, Groningen Radiocarbon Dates V: Radiocar. bon, v. 6 , p. 349-369. 